\title{
AP-2 Family Transcription Factor
}

National Cancer Institute

\section{Source}

National Cancer Institute. AP-2 Family Transcription Factor. NCI Thesaurus. Code

C17545.

Activator Protein 2. Orig inally identified as a cellular transcription factor that binds the enhancer region of SV40. It is encoded by a family of related genes, AP-2 alpha, AP-2 beta, and AP-2 gamma. AP-2 is developmentally regulated and inducible by RET . 